\title{
LAKU DAN PENGETAHUAN SPIRITUAL KI AGENG PANDHANARAN DALAM LAKON WEDHARE SADAT TEMBAYAT
}

\author{
Nada Qonita Mahdiyah", dan Darmoko \\ ${ }^{1,2}$ Universitas Indonesia \\ Emai: Nadaq1797@gmail.com ${ }^{1}$, pak.darmoko@gmail.com ${ }^{2}$
}

\begin{abstract}
Abstrak
Salah satu jenis wayang yang tumbuh dan berkembang di Indonesia adalah Wayang Tauhid. Pergelaran Wayang Tauhid yang didasarkan pada tujuan mensyiarkan agama Islam telah diciptakan oleh seorang dalang bernama Ki Sunardi Wiro Carito. Salah satu lakon yang sarat nilai agama, pengetahuan, dan pesan moral berjudul Wedhare Sadat Tembayat. Untuk mendapatkan pengetahuan keagamaan diperlukan tindakan spiritual dengan laku pengendalian hawa nafsu dan menjauhkan diri dari keramaian duniawi. Penelitian ini bertujuan untuk menguraikan laku di dalam lakon sebagai nilai spiritual keagamaan seperti yang dijalankan oleh Ki Ageng Pandhanaran. Kajian terhadap data menggunakan pendekatan objektif dan metode penelitian deskriptif kualitatif dengan perspektif religi yang ditunjang studi kepustakaan serta kerangka konseptual teoritis Etika Jawa dari Franz Magnis Suseno. Kesimpulan dari penelitian ini bahwa laku yang dijalankan Ki Ageng Pandhanaran menghasilkan pengetahuan keagaman yang diperoleh berdasarkan upaya melalui jalan yang diajarkan oleh Sunan Kalijaga dengan ujian-ujian yang berhasil dikalahkan untuk mencapai tujuan keimanan dan keislaman.
\end{abstract}

Kata kunci : laku, pengetahuan, magi, Wayang Tauhid, Islam

\section{BEHAVIOR AND KNOWLEDGE OF SPIRITUAL KI AGENG PANDHANARAN IN WEDHARE SADAT TEMBAYAT}

\author{
Nada Qonita Mahdiyah ${ }^{1}$, and Darmoko ${ }^{2}$ \\ ${ }^{1,2}$ Universitas Indonesia \\ Nadaq1797@gmail.com ${ }^{1}$,pak.darmoko@gmail.com²
}

\begin{abstract}
One type of puppet that grows and develops in Indonesia is Wayang Tauhid. The performance of the Wayang Tauhid based on the aim of spread Islam has been created by a puppeteer named Ki Sunardi Wiro Carito. One of the plays that is full of religious values, knowledge, and moral messages is entitled Wedhare Sadat Tembayat. To obtain religious knowledge spiritual action is needed with the practice of controlling lust and keeping away from worldly crowds. This study aims to describe laku in the play as religious spiritual values such as those carried out by Ki Ageng Pandhanaran. The study of the data used an objective approach and a qualitative descriptive research method with a religious perspective supported by the literature study and the Javanese Ethical theoretical conceptual framework from Franz Magnis Suseno. The conclusion of this study is that the laku carried out by Ki Ageng Pandhanaran resulted in the knowledge of diversity that was obtained based on efforts through the path taught by Sunan Kalijaga with the exams which were defeated to achieve the goals of faith and Islam.
\end{abstract}

Keywords: Laku, knowledge, magic, Wayang Tauhid, Islam 


\section{PENDAHULUAN}

Eksistensi wayang dalam kebudayaan Jawa masih dapat ditemukan hingga saat ini. Wayang merupakan boneka dari pahatan kulit atau kayu yang difungsikan sebagai tiruan manusia dan dimainkan dengan cerita (lakon) dalam pergelaran (Solichin, 2017:188). Bukan hanya sebagai boneka yang dipergelarkan, wayang mengandung simbolisasi nilai kehidupan dan keluhuran yang terkandung dalam lakon (Solichin, 2016:XVI). Pergelaran wayang tak ubahnya sebagai kesenian yang hingga saat ini dapat ditemui di tengah-tengah masyarakat. Perkembangan kebudayaan di masyarakat mampu menyebabkan lahirnya jenis-jenis wayang yang beragam.

Keberagaman jenis wayang juga berkaitan dengan beragamnya lakon dalam jagat pewayangan. Lakon merupakan alur cerita yang dikisahkan. Lakon berisikan perjalanan tokoh-tokoh wayang yang dihidupkan melalui proses pengelolaan konflik, permasalahan, dan penyelesaian yang dikemas dalam rentetan peristiwa dan membentuk satu kesatuan yang utuh dari jejer hingga tancep kayon (Murtiyoso, 2004:57). Analisis yang baik terhadap lakon yang ada dalam wayang akan menyebabkan terciptanya pemahaman terkait pengetahuanpengetahuan yang ada dalam lakon pewayangan.

Dalam dunia pewayangan, terdapat lakon yang memuat nilai-nilai kehidupan yang berkaitan dengan perjuangan untuk menuju kesempurnaan hidup (Mulyono, 1979:24). Kesempurnaan hidup salah satunya berkaitan dengan keimanan dan aspek-aspek religi seseorang. Religi merupakan sisi kehidupan yang dekat dengan manusia. Wayang yang berkaitan erat dengan religi, salah satunya adalah Wayang Tauhid.

Tauhid merupakan suatu konsep bahwa Allah adalah satu-satunya Tuhan yang dipercaya dan diyakini. Wayang Tauhid merupakan suatu seni pertunjukan yang dipergelarkan dengan tujuan untuk mensyiarkan agama Islam. Kata Tauhid merujuk pada pengertian mengenai keesaan Allah (Woodward, 1999:107). Tauhid mengacu pada pemahaman bahwa Allah adalah Tuhan yang Esa yang merajai kehidupan serta kematian (Koentjaraningrat, 1984:380). Wayang Tauhid merupakan objek kajian yang juga berkaitan dengan Wayang Sadat. Keterkaitan antara kedua objek tersebut terletak pada lakon pergelaran yang bersumber pada nilai-nilai agama Islam. Wayang Sadat dan Wayang Tauhid adalah jenis wayang yang memiliki tujuan sama yakni membawa nafas agama Islam dalam pertunjukan yang dipergelarkan. Secara harfiah, pengertian Sadat adalah sahadat yakni rukun 
Islam pertama yang berkaitan dengan kesaksian seorang hamba terhadap Allah dan Muhammad sebagai Tuhan dan Rasul (Solichin, 2017:7).

Penelitian yang berkaitan dengan Wayang Tauhid dan Sadat beberapa kali telah dilakukan. Adapun penelitian terkait Wayang Sadat berjudul "Resistensi Wayang Sadat dalam Hegemoni Muhammadiyah" yang ditulis oleh Muhammad Mukti pengajar FBS Universitas Negeri Yogyakarta pada tahun 2008, kemudian terdapat pula jurnal berjudul "Proses Evolusi Multilinier Wayang Kulit dan Wayang Sadat" yang ditulis oleh Titin Masturoh pada tahun 2003. Selain itu, hingga jurnal ini dibuat, belum ditemukan penelitian yang berkaitan dengan Wayang Sadat serta Wayang Tauhid. Pencarian telah dilakukan melalui akses terhadap laman-laman internet seperti google scholar dan beberapa situs jurnal seperti Sinta, Garuda, situs jurnal beberapa Universitas yang memiliki program studi Sastra maupun Pendidikan Bahasa Jawa yakni UGM, UNY, Unesa, dan Universitas Indonesia. Penelitian berjudul "Laku dan Pengetahuan Spiritual Ki Ageng Pandhanaran dalam Lakon Wedhare Sadat Tembayat" dituliskan sebagai langkah kebaharuan atas penelitian sebelumnya, terkait kajian atas lakon yang diangkat dalam wayang yang melakukan pembahasan terkait nilai spiritual Islam. Kajian terhadap lakon pada wayang yang sarat akan nilai spiritual Islam (Wayang Sadat dan Tauhid) cukup sukar ditemukan, hal itu juga merupakan salah satu latar belakang mengapa penelitian ini dilakukan.

Berbanding terbalik dengan nasib penelitian terhadap Wayang Tauhid, kajian pustaka mengenai konsep religi cukup mudah dilakukan. Penelitian sejenis yang pernah mengkaji mengenai religi, laku, serta perjalanan hidup telah banyak ditulis. Salah satu penelitian berbentuk skripsi yang mengangkat laku sebagai pembahasan berjudul "Aspek-aspek Laku dalam Serat Seh Jangkung" yang ditulis oleh Lulus Listuhayu pada tahun 2013. Penelitian ini menghasilkan beberapa temuan mengenai aspek-aspek yang berkaitan dengan laku dalam "Serat Seh Jangkung". Temuan dari penelitian itu yakni mengenai laku yang mengandung nilai-nilai syariat, tapa, magi, rasa, sasmita, dan ngelmu dalam laku yang dijalankan oleh Seh Jangkung. Terdapat pula kajian pustaka yang berkaitan dengan perjalanan hidup dan religi yang berjudul "Konsep Darma dalam Budaya Jawa" yang ditulis oleh Darmoko pada tahun 2014. Penelitian ini merumuskan darma sebagai upaya yang dilakukan oleh manusia untuk mencapai nilai-nilai ketuhanan melalui perjalanan suci yang didasarkan atas wahyu dan disertai dengan ujian-ujian (Darmoko, 2014:3). Melalui dua penelitian tersebut terdapat 
konsep laku yakni perjalanan yang dilakukan untuk mencapai suatu tujuan (dapat berwujud religi atau spiritualisme) dengan disertai ujian.

Permasalahan yang ditemukan dalam penelitian ini berkaitan dengan bagaimana konsep laku serta nilai-nilai yang terkandung dalam pergelaran Wayang Tauhid "Lakon Wedhare Sadat Tembayat" (selanjutnya disingkat menjadi WST) digubah oleh seorang dalang bernama Ki Sunardi Wiro Carito berdasarkan kisah yang berkaitan dengan perjalanan Ki Ageng Pandhanaran (selanjutnya disingkat menjadi KAP) sebagai Sunan Tembayat. Sunan Tembayat merupakan julukan yang diberikan oleh Sunan Kalijaga kepada KAP atas kemampuannya menjalankan laku dan membantu mensyiarkan agama Islam. KAP merupakan seorang Bupati Semarang yang dikenal taat dalam menjalani syariat agama, namun seiring berjalannya waktu ada banyak kesalahan yang menyebabkan beliau lalai hingga perlu diingatkan oleh Sunan Kalijaga dan kemudian menjalankan laku (Wahyudi, 2013:48). Konsep laku dan nilai yang telah ditelaah bertujuan untuk menyampaikan bagaimana Wayang Tauhid mewujudkan fungsinya sebagai pertunjukan wayang yang tidak hanya sarat akan nilai kebudayaan, melainkan memiliki fungsi sebagai media dakwah dan penyampaian pesan-pesan terkait keislaman dan keimanan.

Untuk mengetahui nilai-nilai yang terkandung dalam pergelaran Wayang Tauhid, dilakukan pengkajian terhadap lakon yang berjudul "Wedhare Sadat Tembayat". Lakon merupakan ciptaan dari dalang Ki Sunardi Wiro Carito yang mengisahkan tentang perjalanan KAP. Tujuan dari penelitian yakni untuk mengetahui bagaimana laku yang dijalani oleh KAP juga sebagai pengejawantahan pengetahuan spiritual (agama Islam) berdasarkan unsur-unsur yang ada dalam Wayang Tauhid. Termasuk di dalamnya penjabaran mengenai nilai magi yang terkandung dalam lakon.

\section{METODE PENELITIAN}

Lakon WST dapat diteliti melalui data yang berwujud video pertunjukan. Video pertunjukan diperoleh dari koleksi pribadi Ki Sunardi Wiro Carito. Pertunjukan yang direkam berlangsung selama 1 jam 67 menit 44 detik. Pertunjukan digelarkan untuk memperingati hari pendidikan pada tanggal 2 Mei 2013 bertempat di kampus Universitas Widhya Dharma Klaten. Ketika mencari data terkait pertunjukan, terdapat beberapa kendala yang dihadapi. Salah satu kendala dari pencarian data adalah dikarenakan tidak banyak lakon yang 
didokumentasikan dengan baik. WST adalah salah satu dari dua lakon yang pernah dibawakan dan didokumentasikan dengan baik. Selain itu, tidak terdata dengan baik kapan tanggal pelaksanaan pertunjukan.

Selain kendala yang berkaitan dengan sumber data dan keterangan terkait, pencarian data yang sejenis dengan pergelaran Wayang Tauhid sukar dilakukan di laman Youtube. Kurang lebih terdapat tiga hingga empat video yang berisi informasi atau pertunjukan terkait Wayang Tauhid maupun Sadat. Di antaranya adalah pertunjukan Wayang Wali yang diunggah oleh akun Youtube pecinta seni pada tanggal 1 Desember 2015, Java Wayang Sadat yang digelar di Konya Mystic Music Festival diunggah oleh akun vegan108 pada tanggal 27 September 2016, serta "Wayang Tauhid: Wedhare Sadat Tembayat" yang diunggah oleh akun Sunardi Wiro Carito pada tanggal 9 Oktober 2013. Berdasarkan ketiga video tersebut, tidak ada yang memuat pertunjukan secara utuh, namun dipilih video ketiga yang dijadikan objek penelitian dikarenakan memperoleh data pertunjukan setelah melakukan permintaan secara khusus kepada dalang untuk meminta video pertunjukan. Langkah penelitian yang perlu dilakukan setelah berhasil mendapatkan data sebagai objek kajian, selanjutnya dilakukan tahapan-tahapan yang tersusun berdasarkan bagan berikut.

Gambar 1. Tahapan-Tahapan Penelitian

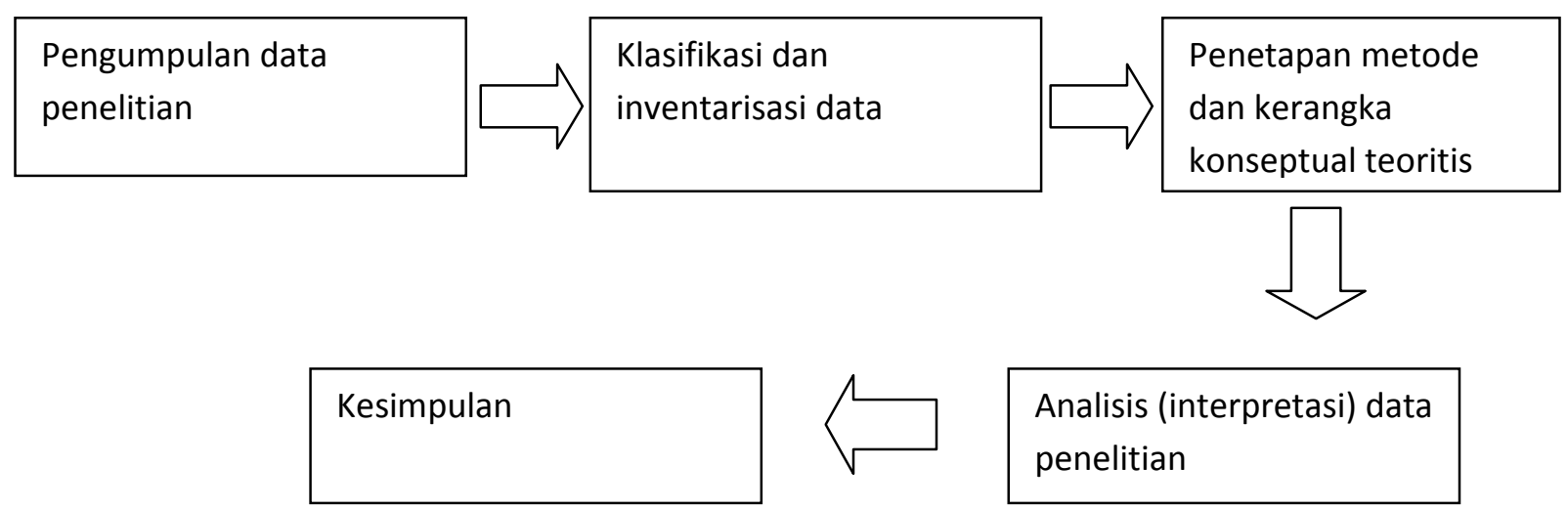

Proses pengerjaan data dari awal hingga kesimpulan terdiri atas tahapan-tahapan yang dituliskan berdasarkan bagan di atas. Pengumpulan data dilakukan dengan melihat laman Youtube dan mencari pergelaran Wayang Tauhid atau Sadat. Setelah pemilihan data yang sesuai, dilakukan transkripsi data pertunjukan serta klasifikasi dan inventarisasi. Klasifikasi dilakukan untuk menemukan percakapan-percakapan yang mengandung nilai-nilai yang dapat 
dikaji dengan teori terkait. Tahapan selanjutya adalah menetapkan metode dan kerangka teori yang sesuai berdasarkan data yang telah diperoleh. Dalam konteks lakon WST ini, teori-teori yang akan digunakan berkaitan dengan unsur religi dan etika Jawa. Teori-teori yang telah ditemukan digunakan sebagai pisau pembedah analisis data hingga ditemukan kesimpulan yang didapat dari pembahasan penelitian.

Metode penelitian menggunakan pendekatan objektif yang melakukan pengkajian pada objek karya sastra. Karya sastra merupakan objek yang akan dijadikan penelitian sesuai dengan pendekatan objektif terhadap karya sebagai kajian utama (Teeuw, 2013:41). Selain itu, akan dilakukan kajian pustaka melalui literatur-literatur yang berkaitan dengan pokok bahasan sebagai salah satu metode penelitian. Penelitian ini menggunakan metode kualitatif dengan melakukan pemaknaan melalui data-data sebagai realitas dan mengolahnya dengan analisis-analisis yang sesuai (Soemantri, 2005:57).

Metodologi penelitian akan dilakukan dengan analisis berdasarkan pada nilai-nilai yang berkaitan dengan etika dalam kehidupan masyarakat Jawa mengenai kehidupan sosial dan religi. Dalam realita sosial di masyarakat, kehidupan antara manusia dan Tuhan merupakan suatu kesatuan yang saling berkaitan satu sama lain. Konsep yang berkaitan dengan etika Jawa ditulis berdasarkan buku "Etika Jawa" yang ditulis oleh Franz Magnis Suseno pada tahun 1984. Etika merupakan nilai-nilai yang ada di masyarakat mengenai bagaimana sikap hidup, tindakan, serta pembawaan yang seharusnya dilakukan sebagai dasar keberhasilan hidup manusia (Suseno, 1984:6). Suseno menyampaikan bahwa keberhasilan hidup berkaitan dengan keberhasilan (untuk) hidup sebagai manusia dengan mendapatkan pengakuan terhadap sistem sosial masyarakat, berbahagia, serta mampu melakukan pemenuhan terhadap takdir Tuhan (1984:6). Konsep yang digunakan berkaitan dengan dunia kehidupan sosial masyarakat Jawa seperti pengendalian hawa nafsu, kedudukan pemimpin, serta takdir yang berkaitan dengan kehidupan manusia. Menurut De Jong, kesempurnaan hidup merupakan perihal lahir dan batin, yakni menjalankan tugas manusia sebagai utusan Tuhan untuk membentuk masyarakat yang sejahtera agar terwujud ketertiban serta ketentraman (1976:23). Dalam makna lain, kesempurnaan hidup dapat diraih berdasarkan keselarasan antara individu serta masyarakat agar menerapkan nilai-nilai sosial sehingga mampu hidup dalam ketentraman. Konsep-konsep tersebut menjadi dasar pemikiran dari analisis terhadap lakon WST. 
Lakon yang berkaitan dengan perjuangan kehidupan yang dilakukan oleh salah satu tokoh sebagai sarana untuk menuju kehidupan yang sempurna dan suci merupakan bentuk tasawuf atau perjalanan hidup yang juga berkaitan dengan kekuatan adikodrati (Mulyono, 1979:24). Melalui hal-hal yang dapat diketahui bahwa wayang mengandung ilmu pengetahuan tentang keimanan termasuk terkait perjalanan kehidupan yang berkaitan dengan kesempurnaan hidup maka dilakukan analisis terkait lakon WST menggunakan konsepkonsep yang berkaitan dengan tasawuf dan pengetahuan.

\section{HASIL DAN PEMBAHASAN}

\section{Perjalanan Laku KAP}

Lakon WST mengisahkan tentang perjalanan laku yang dijalani oleh KAP menuju gunung Jabalkat atas anjuran yang disampaikan oleh Sunan Kalijaga sebagai upaya bertaubat dari kesalahan-kesalahan yang dilakukan selama hidup. Laku berdasarkan makna kata merujuk pada kehidupan yang didasari atas konsep dinamis (Rahyono, 2015:160). Hidup didasarkan pada upaya-upaya yang dilakukan oleh manusia untuk selalu berusaha dan bergerak hingga sampai pada titik yang diinginkan. Keinginan dari KAP dalam lakon WST adalah untuk mendapatkan pengetahuan tentang keimanan sehingga mampu melebur dosa atas perbuatan yang pernah dilakukan.

Laku yang dijalankan oleh KAP merupakan perjalanan yang ditempuh atas perintah Sunan Kalijaga sebagai upaya taubatan nasuha. Taubatan nasuha merupakan upaya seorang manusia untuk memperbaiki kesalahan yang pernah dilakukan atas dirinya berdasarkan penyesalan yang mendalam serta tekad untuk tidak mengulanginya (Muhammad Syaiful Hidayat \& Yunus Hanis Syam, 2009:34). Taubatan nasuha yang diimpikan oleh KAP timbul dari dalam diri pribadi. Kesadaran ini muncul ketika mendapati bahwa hati dan batinnya dalam keadaan yang selama ini kosong, tidak disinari cahaya ilahi barang sedikitpun, sehingga peteng dhedhet klimengan kopong 'gelap gulita (selalu) lupa dan kosong'. Gelap gulita sebagai padanan untuk menggambarkan hati yang tidak diterangi oleh cahaya ilahi yang dicerminkan sebagai sumber kearifan dan ketuhanan (Sviri, 2006:18). Kondisi hati KAP yang gelap gulita memiliki makna bahwa ia tidak dihidupi dengan nilai-nilai ketuhanan serta kearifan. 
Dalam mistik Islam dan Jawa, Tuhan memiliki tempat di dalam hati sanubari manusia yang akan mencapai tempatnya (hati sanubari), jika manusia dapat melepaskan penutuppenutup yang menutupi dan menghalangi (Zoetmulder, 1990:214). Penutup-penutup yang menghalangi masuknya kesadaran terhadap diri pribadi adalah nafsu yang keberadaannya perlu dikendalikan, sehingga mampu mencapai kesempurnaan. Kesempurnaan dapat diwujudkan salah satunya dengan mempelajari ajaran-ajaran yang berkaitan dengan ilmu tasawuf (Simuh, 1988:289). Tasawuf merupakan jalan untuk mencapai penghayatan makrifat kepada Tuhan dengan menghilangkan sifat-sifat yang tercela dan menyucikan diri (Simuh, 1988:342). Perjalanan ini yang sedang dilakukan oleh KAP sebagai upaya untuk mewujudkan kehidupan kerohanian agar lebih dekat dengan Tuhan. Mencari kedekatan diri dengan melakukan perjalanan menuju tempat yang ditunjukkan oleh Sunan Kalijaga dengan melebur hawa nafsu serta keduniawian merupakan bentuk tasawuf yang dikisahkan dalam lakon WST ini.

Salah satu ajaran yang memuat ilmu tasawuf adalah Serat Wirid Hidayat Jati. Dalam serat Wirid Hidayat Jati, memuat ajaran mengenai ajaran mistik dalam Islam bertujuan untuk mencapai kesatuan terhadap Tuhan dalam konsep manunggaling kawula gusti (Simuh,1988:289). Konsep manunggaling kawula gusti merupakan bentuk perwujudan citacita yang diinginkan oleh manusia untuk menyatukan kehidupan dengan Tuhan (Simuh, 1988:289). Cita-cita tersebut yang menjadi dasar upaya-upaya makrifat untuk menemukan kesempurnaan. Makrifat merupakan jalan yang dapat dilakukan untuk mengenali Tuhan yang dicapai dengan upaya pribadi. Perjalanan pencarian Tuhan dalam laku yang dijalankan oleh KAP merupakan perwujudan konsep pencarian keimanan dalam diri manusia.

Setiap manusia yang sadar akan berusaha mencapai jalan menuju makrifat. Dalam dunia kebudayaan Jawa pencapaian kesempurnaan yang dicapai melalui jalan spiritual memiliki cara yang beragam. Berikut akan diuraikan pencapaian yang didapat oleh tokoh dalam WST berdasarkan peristiwa serta laku sebagai wujud upaya mencapai kesempurnaan hidup. 
Tabel 1. Peristiwa, Tokoh-tokoh yang Terlibat, dan Jenis Ujian dalam Laku

\begin{tabular}{|c|c|c|c|c|}
\hline Latar & Deskripsi Peristiwa & $\begin{array}{c}\text { Tokoh-tokoh yang } \\
\text { Terlibat }\end{array}$ & $\begin{array}{l}\text { Jenis Ujian atau Amanat yang } \\
\text { Diperoleh }\end{array}$ & $\begin{array}{l}\text { Pencapaian } \\
\text { Laku }\end{array}$ \\
\hline Semarang & $\begin{array}{l}\text { Terjadi perselisihan } \\
\text { antara Kajabur dengan } \\
\text { Tumenggung, Patih, dan } \\
\text { Ranawijaya yang } \\
\text { diakhiri dengan peristiwa } \\
\text { magi ketika muncul } \\
\text { bongkahan emas dari } \\
\text { dalam tanah setelah } \\
\text { digali oleh Kajabur. }\end{array}$ & $\begin{array}{l}\text { KAP, Kajabur } \\
\text { (penyamaran Sunan } \\
\text { Kalijaga sebagai } \\
\text { rakyat kecil), Sunan } \\
\text { Kalijaga, } \\
\text { Tumenggung, } \\
\text { Patih. }\end{array}$ & $\begin{array}{l}\text { Menyaksikan peristiwa yang } \\
\text { cukup hebat berupa } \\
\text { munculnya emas dari } \\
\text { bongkahan tanah sehingga } \\
\text { membuat sikap tamak dan } \\
\text { keinginan untuk lebih unggul } \\
\text { dari orang lain. }\end{array}$ & $\begin{array}{l}\text { Eksistensi } \\
\text { diri }\end{array}$ \\
\hline Salatiga & $\begin{array}{l}\text { Perjalanan KAP } \\
\text { dihadang oleh ketiga } \\
\text { orang begal yang ingin } \\
\text { merampas harta benda } \\
\text { yang sedang dibawa. }\end{array}$ & $\begin{array}{l}\text { KAP, Nyi } \\
\text { Ranawijaya, ketiga } \\
\text { orang begal Sodrun, } \\
\text { Bandrun, Ganjul. }\end{array}$ & $\begin{array}{l}\text { Ujian untuk meninggalkan } \\
\text { harta benda yang dimiliki } \\
\text { sebagai salah satu nafsu yang } \\
\text { harus dihilangkan dari dalam } \\
\text { diri ketika menjalankan laku. }\end{array}$ & $\begin{array}{l}\text { Pelepasan } \\
\text { kepemilikan } \\
\text { harta }\end{array}$ \\
\hline Boyolali & $\begin{array}{l}\text { Nyi Ageng Pandhanaran } \\
\text { ditinggalkan oleh KAP } \\
\text { ketika sedang dalam } \\
\text { perjalanan hingga tiba di } \\
\text { daerah yang akhirnya } \\
\text { dinamakan Boyolali. }\end{array}$ & Nyi Ranawijaya & $\begin{array}{l}\text { Ujian kesabaran atas peristiwa } \\
\text { yang dialami oleh Nyi } \\
\text { Pandhanaran. Ujian untuk } \\
\text { merelakan isterinya sebagai } \\
\text { salah satu simbol pengelolaan } \\
\text { hawa nafsu duniawi. }\end{array}$ & $\begin{array}{l}\text { Keikhlasan } \\
\text { melepas } \\
\text { keterikatan } \\
\text { terhadap } \\
\text { isteri }\end{array}$ \\
\hline Wedhi & 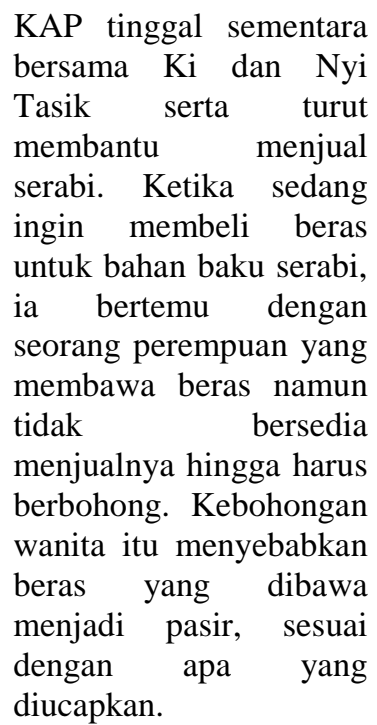 & $\begin{array}{l}\text { Ki Tasik, Nyi } \\
\text { Tasik, perempuan } \\
\text { pembawa beras, } \\
\text { KAP. }\end{array}$ & $\begin{array}{l}\text { Amanat terkait dengan } \\
\text { kejujuran terhadap diri sendiri. } \\
\text { Perbuatan membohongi orang } \\
\text { lain tidak lebih dari } \\
\text { pembohongan terhadap diri } \\
\text { sendiri, dan sesunguhnya } \\
\text { setiap manusia tidak akan } \\
\text { mampu mendustakan apa } \\
\text { yang ada dalam hatinya. }\end{array}$ & $\begin{array}{l}\text { Pentingnya } \\
\text { jujur } \\
\text { terhadap diri }\end{array}$ \\
\hline Jabalkat & \begin{tabular}{lr} 
KAP telah tiba di \\
gunung Jabalkat dan \\
telah & berhasil \\
menyelesaikan & \\
perjalanan & yang \\
berkaitan rang & dengan \\
pencapaian keimanan \\
\multicolumn{2}{l}{ serta pengetahuan. }
\end{tabular} & $\begin{array}{l}\text { KAP dan Sunan } \\
\text { Kalijaga }\end{array}$ & $\begin{array}{l}\text { Amanat yang disampaikan } \\
\text { oleh Sunan Kalijaga berkaitan } \\
\text { dengan keimanan serta } \\
\text { penetapan KAP oleh Sunan } \\
\text { Kalijaga sebagai wali lukba } \\
\text { (wali penutup dari walisanga, } \\
\text { keterangan disampaiakan oleh } \\
\text { Sunan Kalijaga pada akhir } \\
\text { lakon) dengan nama Sunan } \\
\text { Tembayat. }\end{array}$ & $\begin{array}{l}\text { Pencapaian } \\
\text { kespiritualan }\end{array}$ \\
\hline
\end{tabular}


Pada tabel menunjukkan bahwa peristiwa-peristiwa di dalamnya berkaitan dengan ujian yang dialami oleh KAP. Ujian-ujian yang dialami merupakan bentuk halangan yang perlu dilalui untuk memperjuangkan upaya menuju tempat yang dituju. Ujian-ujian berkaitan pula dengan kesungguhan KAP untuk menjalani laku. Ujian pertama yang dirasakan berkaitan dengan peristiwa Salatiga. Di perjalanan, KAP dihadang oleh sekelompok begal yang ingin merampas harta benda yang dibawa. Beruntungnya KAP sudah membebaskan diri dari belenggu hawa nafsu yang berkaitan dengan harta benda. Ujian ini berkaitan dengan keikhlasan dan pelepasan (terhadap kepemilikan harta) yang harus dilakukan untuk mencapai keadaan sempurna bebas dari hawa nafsu yang membelenggu. Begitu juga terkait ujian yang ditemui berikutnya. Segala macam ujian yang ditempuh bertujuan untuk meneguhkan tekad dan keyakinan dalam menjalani laku.

\section{Realitas Ki Ageng Pandhanaran sebagai Pemimpin}

Perjalanan laku KAP tidak terlepas pada realitas bahwa ia merupakan seorang pemimpin. Sosok KAP yang menduduki posisi sebagai adipati Semarang akan dinilai berdasarkan sifatnya sebagai pemimpin. Sikap kepemimpinan yang terdiri atas nilai-nilai idealisme sebagai seorang pemimpin perlu dimiliki guna mewujudkan kehidupan yang selaras. Menduduki posisi yang vital terhadap keberlangsungan masyarakat dan kehidupan salah satu nilai yang harus dimiliki adalah kearifan. Kebudayaan yang sejatinya menjunjung tinggi kearifan, menuntut pemimpin untuk memiliki sifat arif 'nguwongke' atau memperlakukan orang lain selayaknya pribadi yang perlu dihormati (Rahyono, 2015:215). Pemimpin merupakan perwujudan tokoh yang memiliki kedudukan serta berperan dalam menunjukkan keteladanan sikap. Salah satu sikap yang baik dan diposisikan penting adalah sikap hormat. Menghormati orang lain merupakan wujud dari pengendalian ego keakuan sebagai pemimpin. Pemimpin yang dapat 'manjing ajer-ajer' atau dapat melebur dan menghargai masyarakat sebagai individu yang bermartartabat sama seperti dirinya merupakan kearifan yang perlu dimiliki (Rahyono, 2015:215).

Tidak selaras dengan nilai-nilai kearifan yang perlu dimiliki oleh seorang pemimpin, KAP justru menunjukkan sikap-sikap yang kurang arif. Selain KAP, penggambaran sikap pemimpin yang tidak baik diperankan oleh tumenggung dan patih. Tumenggung dan patih merupakan dua jabatan yang berada di bawah kepemimpinan adipati. Termasuk ke dalam 'wong ningrat' atau bangsawan, patih dan tumenggung melakukan tindakan sewenang- 
wenang terhadap rakyat. Rakyat yang diposisikan sebagai orang yang tidak memiliki jabatan apapun dalam pemerintahan, dianiaya dan dianggap tidak memiliki wewenang untuk berpendapat dan mengkritik KAP.

Gambaran posisi rakyat yang dianiaya oleh tumenggung dan patih diwakilkan oleh tokoh Kajabur. Kajabur yang dianggap melawan KAP karena menyampaikan nasihat serta peringatan terkait sikap-sikap yang tidak pantas dilakukan oleh adipati justru harus merasakan perlakuan yang tidak baik. Sikap-sikap yang dikritisi oleh Kajabur berkaitan dengan KAP sebagai pemimpin yang seharusnya menerima masukan dari orang lain. Dalam menyampaikan pendapat yang berkaitan dengan KAP, Kajabur sudah memposisikan diri sebagai 'wong cilik ongklak-angklik' yakni seorang individu merujuk pada rakyat kecil yang tidak memiliki jabatan apapun. Berikut merupakan bentuk percakapan antara Kajabur, patih serta tumenggung.

Patih: "Kowe wong cilik ongklak-angklik. Wani mejang (mulang bab ngelmu kasampurnan) karo kanjeng Adipati. Kaya wus suci-sucia dhewe. Bubar meguru anyar ya kowe."

Kajabur: "Wadhuh gusti. Gusti Patih. Kula sadreme ngemutaken awit wus tinulis watawasshaubil haqi watawa saubis sabr. Sedaya tiyang menika menawi saged dipun ling-wineling wonten ing kesabaran, ling-wineling wonten ing kesaenan lha kok kula malah dipunlepataken iku wonten pundi? Menika menawi boten wonten ingkang wantun ngemutaken dhateng kainggilan. Boten wonten ing kengaken priyantun inggil. Wala, dunya niki bakal bubrah Ki Patih, nek pun bubrah, wonten kahanan ingkang nggegirisi."

Tumenggung: “Wayah! Kaya isa-isaa ngramal! Gunenmu kaya majnun, Rumangsamu ora ngerti sopan santun, kowe iki wong apa ta?.”

Terjemahan

Patih: "Kamu (hanya) orang kecil, berani betul menggurui (mengajarkan tentang ilmu kasampurnan) kepada Adipati, seakan-akan (merasa) paling suci, kamu telah mempelajari ilmu baru ya."

Kajabur: "Adhuh tuan. Tuan Patih. Saya sekedar mengingatkan, sebab telah tertulis watawasshaubil haqi watawa saubis sabr. Semua orang sebisa mungkin saling mengingatkan terkait kesabaran dan kebaikan. Mengapa saya disalahkan? Jika tidak ada yang berani mengingatkan tentang kebaikan, maka tidak ada orang yang benar (baik). Wah dunia ini akan rusak Ki Patih, jika sudah rusak, akan ada tempat yang menakutkan (nggegilani, medeni)."

Tumenggung: "Wayah! (kata yang menyatakan seruan) seakan dapat meramal! Perkataanmu seperti orang bodoh, seakan tidak memiliki sopan santun, kamu ini orang (seperti) apa." 
Melalui percakapan singkat yang diuraikan di atas, terdapat suatu fenomena bahwa tumenggung dan patih merupakan orang yang memerankan posisi sebagai pejabat yang tidak menerima masukan dari rakyat kecil.

Pengakuan terhadap posisi dirinya menyebabkan para pemimpin semakin merasa berkuasa dan semena-mena dalam memperlakukan Kajabur. Pemimpin yang semena-mena sesungguhnya memiliki perasaan ingin diposisikan sebagai orang yang lebih tinggi dengan sikap 'sapa sira sapa ingsun' yang dapat diartikan sebagai penekanan terhadap kesadaran bahwa dirinya memiliki jabatan, sehingga 'siapa kamu dan siapa saya' berlaku (Rahyono, 2015:215). Sikap ini tentu tidak sesuai dengan nilai-nilai kearifan kepemimpinan yang diharapkan bahwa pemimpin dapat melebur dan tidak melakukan tindakan semena-mena.

Konsep kepemimpinan dalam kearifan budaya Jawa diwakilkan dengan ungkapan drajat, pangkat, semat, bisa oncat yang dapat dimaknai sebagai kedudukan jabatan yang tidak langgeng dan dapat hilang (segala sesuatu) kapan saja (Endraswara, 2013:153). Oleh karena sifatnya yang hanya bersifat sampiran, tidak bijak jika meletakkan jabatan sebagai posisi yang dibanggakan dan digunakan untuk menyombongkan diri. Perasaan eksklusif terhadap kedudukan sebagai pemimpin sehingga tidak berbaur serta berani bertindak sewenangwenang merupakan suatu sikap yang bertentangan dengan kesesuaian nilai. Pelanggaran nilai kepemimpinan yang dilakukan oleh KAP serta dua orang anak buahnya merupakan kesalahan yang dilakukan oleh seorang manusia yang belum menemukan jalan kebenaran.

\section{Pengendalian Hawa Nafsu}

Sikap sewenang-wenang ketika menjadi pemimpin merupakan bentuk kehilangan pengendalian terhadap hawa nafsu. Jalan kebenaran yang menjadi tujuan KAP dimulai dengan proses pengendalian hawa nafsu. Empat jenis nafsu yang dipercayai oleh masyarakat Jawa yakni nafsu amarah, aluwamah, supiyah, dan mutmainah (Wahyudi, 2014:175). Pada dasarnya nafsu merupakan naluri alamiah yang dimiliki oleh manusia yang lebih mendorong pada kesenangan duniawi (Simuh, 1988:340). Nafsu amarah merupakan perwujudan sikap yang penuh dengan keangkaramurkaan, iri, dan mudah marah. Nafsu lawwamah bersumber dari dalam perut dan berkaitan dengan hal-hal seperti nafsu lapar, makan, dan tidur. Selanjutnya, nafsu yang berkaitan dengan perasaan cinta atau hasrat serta kesenangan yang berhubungan dengan perasaan disebut dengan nafsu sufiyah. Nafsu mutmainah berhubungan dengan keinginan baik yang mewujudkan ketentraman seperti berpuasa atau tapa brata tanpa 
mengenal batasan. Nafsu-nafsu tersebut meski yang terlihat baik sekalipun, perlu dilakukan pengendalian. Setiap manusia memiliki hawa nafsu yang perlu dikendalikan sehingga tidak hanya bertujuan untuk kesenangan duniawi saja.

Hawa nafsu merupakan sifat-sifat yang erat kaitannya dengan keduniawian oleh karena itu pengendalian hawa nafsu yang ada dalam diri perlu diupayakan sehingga manusia dapat mengenali diri sejati (Wahyudi, 2014:188). Pengendalian hawa nafsu merupakan aspek yang penting dalam proses pengamalan ilmu religi yang berkaitan dengan kesempurnaan hidup sebagai manusia. Hawa nafsu merupakan rintangan terbesar yang akan menghalangi manusia menuju kemanunggalan, sehingga perlu dikendalikan dan dihilangkan pengaruhnya (Simuh, 1988:294). Pengendalian yang baik terhadap hawa nafsu yang ada dalam diri manusia akan menghasilkan sikap waspada dan ingat dan akan membawa pada kemuliaan (sifat). Oleh karena itu, KAP menjalankan laku sebagai upaya pengendalian nafsu-nafsu yang ada pada dirinya untuk mencapai jalan kemanunggalan dengan Tuhan.

\section{Taubat sebagai Introspeksi Diri}

Upaya pengendalian hawa nafsu yang ada dalam diri KAP dilakukan atas kesadaran untuk menjalankan taubat. Taubatan nasuha yang hendak dilaksanakan oleh KAP merupakan perwujudan dari keinginannya untuk memperbaiki kesalahan yang pernah dilakukan sehingga dapat menjadi insan yang lebih baik lagi. Pengetahuan, kondisi hati, dan kesadaran merupakan hal-hal yang menjadi dasar dari taubat (Shohib, 2015:531). Tekad dan niatan untuk melakukan taubatan nasuha disampaikan oleh KAP kepada Sunan Kalijaga atas dasar kesadaran akan kesalahan yang telah dilakukannya selama menjadi pemimpin di Semarang.

Taubatan nasuha yang akan dilakukan oleh KAP berdasarkan ajaran yang disampaikan oleh Sunan Kalijaga. Sunan Kalijaga merupakan salah satu tokoh walisanga yang memiliki peran besar dalam penyebaran agama Islam di pulau Jawa khususnya (Dandhel, 2013:8). Sunan Kalijaga merupakan tokoh 'ingkang wus putih njaba lan jerone' yakni sudah memiliki baik secara wujud maupun batin. Masyarakat Jawa meyakini bahwa Sunan merupakan salah satu orang-orang keramat yang memiliki peran dalam hal keagamaan salah satunya penyebaran agama Islam (Koetjaraningrat, 1984:324). Dalam melakukan penyebaran agama Islam, salah satu hal yang dilakukan adalah mengajarkan syariat atau makna agama kepada masyarakat luas. Oleh karena itu, Sunan Kalijaga menuntun KAP untuk melakukan taubatan nasuha dengan kekuatan tekad yang harus dimiliki dalam hati. Sunan 
Kalijaga memerintah KAP untuk berjalan menuju gunung Jabalkat guna mendatangi dirinya, sehingga dapat mempelajari ilmu agama atau kehidupan bersama. Berikut pesan yang disampaikan oleh Sunan Kalijaga.

Sunan Kalijaga: "Mung welingku ya Ngger, Rana Wijaya lan kabeh wae. Yen sira bakal munggah ing gunung suci, munggah ning gunung suci, tinggalno bandha donya Ngger."

Terjemahan

Sunan Kalijaga: “Tetapi (ingatlah) pesanku ya Ngger, Rana Wijaya dan siapa saja, jika kalian akan naik menuju gunung suci (Jabalkat), naik menuju gunung suci, tinggalkanlah harta benda (yang dimiliki)."

Melalui pesan yang disampaikan oleh Sunan Kalijaga tersebut, maka perjalanan laku yang akan ditempuh oeh KAP merupakan perjalanan yang harus disertai kesungguhan secara mental dan keikhlasan untuk melepaskan segala hal yang berkaitan dengan keduniawian. Keduniawian dalam konteks ini adalah harta benda. Masyarakat Jawa yang arif beranggapan bahwa kehidupan tidak bertujuan untuk mengumpulkan harta serta kekayaan, akan tetapi terdapat untuk mewujudkan kehidupan tentrem atau selamet (Endraswara, 2016:239). Oleh karena itu, KAP ingin mencari ketentraman dan keselamatan dalam hidup. Dengan tujuan yang jelas, KAP berangkat menuju Jabalkat ditemani oleh Nyi Pandanaran. Untuk mewujudkan perjalanan yang sesuai dengan aturan dan pesan Sunan Kalijaga, KAP rela meninggalkan segala hal yang dimiliki seperti jabatan sebagai adipati serta harta benda yang dimiliki.

\section{Peristiwa Magis dan Penamaan suatu Daerah}

Perjalanan KAP untuk bertaubat dalam upaya kemanunggalan dengan pelepasan hawa nafsu disertai peristiwa-peristiwa yang sarat akan kekuatan adikodrati. Suatu peristiwa yang berkaitan dengan kekuatan-kekuatan adikodrati atau rahasia (tidak dapat dijelaskan nalar manusia) merupakan sekti (Berg, 1985:9). Kesaktian merupakan kekuatan khusus yang tidak dapat dilakukan oleh semua orang (secara umum). Peristiwa yang menampakkan kekuatan magi dapat ditemui dalam lakon WST beberapa kali. Umumnya yang muncul dalam lakon ini adalah peristiwa magi yang berkaitan dengan kesaktian kata. Kata-kata yang memiliki kekuatan magi berkaitan dengan ucapan yang disampaikan oleh tokoh tertentu. Kekuatan kesaktian kata yang diucapkan bergantung pada individu yang menuturkan kata tersebut 
(Berg, 1985:42). Umumnya, orang-orang dengan kepemilikan ilmu pengetahuan yang lebih akan dianggap memiliki kekuatan magis.

Tokoh yang menampakkan diri memiliki kekuatan magis sebagai takdir dari Tuhan dalam lakon WST adalah Sunan Kalijaga dan KAP. Adapun kejadian-kejadian yang memuat daya magis adalah ketika berada di Semarang, Salatiga, dan desa Wedhi (pasir).

Tabel 2. Nilai Magis dalam Laku Ki Ageng Pandhanarang

\begin{tabular}{|c|c|c|c|c|c|c|}
\hline No. & $\begin{array}{c}\text { Tempat } \\
\text { Kejadian }\end{array}$ & $\begin{array}{c}\text { Tokoh yang } \\
\text { Terlibat }\end{array}$ & $\begin{array}{l}\text { Peristiwa yang } \\
\text { terjadi }\end{array}$ & Penyebab & $\begin{array}{c}\text { Hal yang } \\
\text { dilakukan setelah } \\
\text { kejadian } \\
\end{array}$ & Laku \\
\hline 1. & Semarang & $\begin{array}{l}\text { KAP dan } \\
\text { Kajabur }\end{array}$ & $\begin{array}{l}\text { Muncul } \\
\text { bongkahan emas } \\
\text { dari dalam tanah } \\
\text { yang dicangkul } \\
\text { oleh Kajabur } \\
\text { (Sunan } \\
\text { Kalijaga). }\end{array}$ & $\begin{array}{l}\text { Kajabur } \\
\text { diperintahkan } \\
\text { untuk } \\
\text { menunjukkan } \\
\text { kemampuannya } \\
\text { mengungguli } \\
\text { kekayaan } \\
\text { kadipaten } \\
\text { Semarang. }\end{array}$ & $\begin{array}{l}\text { KAP kaget dan } \\
\text { menganggap itu } \\
\text { tipuan Kajabur } \\
\text { (sulap), namun } \\
\text { kemudian mata } \\
\text { batinnya terbuka } \\
\text { dan ingin } \\
\text { bertaubat. }\end{array}$ & Bertaubat \\
\hline 2. & Salatiga & $\begin{array}{l}\text { KAP dan } \\
\text { tiga begal } \\
\text { bernama } \\
\text { Sodrun, } \\
\text { Badrun, dan } \\
\text { Ganjul. }\end{array}$ & $\begin{array}{l}\text { Ketiga orang } \\
\text { begal yang } \\
\text { hendak } \\
\text { merampas harta } \\
\text { benda yang } \\
\text { dibawa oleh } \\
\text { KAP berubah } \\
\text { menjadi domba. }\end{array}$ & $\begin{array}{l}\text { Tidak percaya } \\
\text { akan perkataan } \\
\text { KAP bahwa ia } \\
\text { tidak membawa } \\
\text { harta. }\end{array}$ & $\begin{array}{l}\text { Ketiga begal } \\
\text { masuk Islam dan } \\
\text { dijuluki Seh } \\
\text { Dumbo. } \\
\text { Diwajibkan } \\
\text { mengikuti } \\
\text { perjalanan KAP } \\
\text { dan tapa ngrame. }\end{array}$ & $\begin{array}{l}\text { Tapa } \\
\text { ngrame }\end{array}$ \\
\hline 3. & $\begin{array}{l}\text { Desa } \\
\text { Wedhi }\end{array}$ & $\begin{array}{l}\text { Seorang } \\
\text { perempuan } \\
\text { pembawa } \\
\text { beras dan } \\
\text { KAP. }\end{array}$ & $\begin{array}{l}\text { Beras yang } \\
\text { dibawa seketika } \\
\text { berubah menjadi } \\
\text { pasir. }\end{array}$ & $\begin{array}{l}\text { Berbohong } \\
\text { kepada KAP } \\
\text { bahwa ia tidak } \\
\text { membawa beras. }\end{array}$ & $\begin{array}{l}\text { Beras berubah } \\
\text { menjadi pasir dan } \\
\text { perempuan } \\
\text { tersebut } \\
\text { menyampaikan } \\
\text { bahwa desa yang } \\
\text { sedang dilaluinya } \\
\text { akan bernama } \\
\text { desa Wedhi. }\end{array}$ & $\begin{array}{l}\text { Pencapaian } \\
\text { kesaktian }\end{array}$ \\
\hline
\end{tabular}

Tabel di atas memuat bagaimana peristiwa-peristiwa yang mengandung daya magis terjadi. Peristiwa yang terjadi merupakan rentetan kejadian yang diurutkan berdasarkan waktu kejadian. Peristiwa magis yang pertama kali terjadi berkaitan dengan tantangan yang dismpaikan oleh KAP kepada Kajabur untuk membuktikan ucapannya ketika berkata bahwa harta benda bukan hal yang penting dan ia dapat mengumpulkan kekayaan (juga). Peristiwa kedua ketika KAP sedang dibegal kemudian menunjukkan bahwa yang membawa harta adalah isterinya, namun ketiga begal tidak percaya sehingga diucapkan kata-kata yang 
berkaitan dengan sikapnya yang tidak baik selayaknya wedhus (kambing). Seketika ketiga begal tersebut menjadi kambing. Peristiwa terakhir berkaitan dengan perubahan beras yang menjadi pasir dikarenakan kebohongan yang diucapkan oleh seorang wanita.

Magis yang terjadi dikaitkan dengan kemampuan Tuhan. Terdapat kemampuan yang dianggap sebagai perwujudan kekuatan gaib yang telah mengatur kehidupan manusia di dunia (Rahyono, 2015:178). Peristiwa-peristiwa itu dikisahkan sebagai akibat dari perbuatan yang harus dirasakan oleh manusia. Kekuatan yang sifatnya magis dijelaskan sebagai perwujudan kekuasaan Tuhan yang disampaikan melalui kisah-kisah dalam perjalanan KAP menuju gunung Jabalkat. Kekuasaan Tuhan untuk menentukan takdir manusia dan mewujudkan kekuatan-kekuatan yang bahkan diluar dari nalar manusia. Melalui peristiwaperistiwa itu pengenalan pengetahuan mengenai kekuasaan Tuhan dan perlunya sikap hatihati terhadap apa yang dilakukan dan diucapkan agar tidak mendapatkan kerugian selayaknya tokoh-tokoh dalam lakon.

Kekuasaan Tuhan juga diungkapkan melalui penamaan-penamaan daerah. Masingmasing daerah tersebut adalah Salatiga, Boyolali, dan desa Wedhi. Penamaan daerah berdasarkan hal-hal yang terjadi dan dialami oleh tokoh. Penamaan daerah Salatiga merupakan akibat dari perbuatan yang berkaitan dengan kesalahan yang dilakukan oleh ketiga orang begal (perampok) yang meminta harta benda KAP ketika sedang dalam perjalanan. Ketiga orang ini kemudian ditakdirkan berubah wujud menjadi domba dan daerah tersebut dinamakan Salatiga sebab mengingatkan pada ketiga orang yang telah melakukan kesalahan.

KAP: "Iya, kowe nganggo sesebutan Seh Dumbo lan kanggo pangeling-eling kowe sakkancamu gandheng sing salah kuwi kancamu telu, muga-muga ing leladan kene besok yen ana rejane jaman, katlaut desa salahtiga."

Terjemahan

KAP: "Iya kamu menggunakan julukan Seh Dumbo dan untuk menjadi pengingat, dikarenakan ketiga temanmu yang bersalah (menjadi begal dan merampas harta) semoga jika ada kemakmuran, desa ini akan dikenal dengan sebutan salatiga."

Daerah selanjutnya yang dinamakan dalam lakon ini adalah Boyolali. Dalam lakon WST ini, Boyolali merupakan daerah kedua yang diberi nama oleh Nyai Pandhanaran. Disebabkan oleh kejadian terpisahnya KAP dengan Nyai Pandhanarang muncul perasaan kecewa dan sedih hingga menganggap bahwa sang suami sudah tidak mengingatnya lagi. Oleh karena itu daerah tersebut dinamakan Boyolali. 
Nyai Pandhanarang: "Bat tobat, tobat.. tobat...tobat... apa wis ora tresna tenan Kangmas Adipati ninggalake lakuku. Bot bote aku wanita kubyuk kabot jang pinjung kya wis tak gelak-gelakna lakuku. Nanging aku ora wis kuwawa. Bat tobat yo baya. Baya wis lali marang aku Kangmas Adipati. Wis lali tenan marang aku, Kangmas. Ya ta ya kanggo pangeling-elingku muga-muga Desa narajane jaman Desa kene katelaka Boyolali."

Terjemahan

Nyai Pandhanarang: "Bat tobat, tobat, tobat. Apa benar Kangmas Adipati sudah tidak mencintai hingga meninggalkan saya. Aku perempuan yang telah berjalan dengan usaha yang besar hingga benar-benar kuupayakan laku ini, akan tetapi aku sudah tidak kuat. Bat tobat ya boya. Kiranya telah lupa kepadaku Kangmas Adipati. Benarbenar sudah melupakanku, Kangmas. Ya untuk mengingatkanku, jika desa ini makmur maka akan dikenal dengan nama Boyolali."

Daerah terakhir yang diberi nama pada lakon ini adalah desa Wedhi. Desa Wedhi yang berarti pasir diberi nama demikian dikarenakan peristiwa berubahnya wujud beras yang dibawa oleh seorang wanita paruh baya menjadi pasir. Perubahan wujud tersebut diasumsikan karena perbuatannya yang tidak jujur terhadap diri ketika mengelak menjual beras yang dibawa. Ketika KAP sedang membutuhkan beras, ia justru mengatakan bahwa yang dibawanya bukan beras. Seketika beras tersebut berubah wujud menjadi pasir. Berikut merupakan percakapan yang terkait dengan peristiwa ini.

Perempuan: "Tobat..tobat..tobat lah wong yah ene kok ya ana wong sing nyegat ning dalan. Ora ngerti wong kae ya begal sing ora duwe gaweyan. Hah. Beras apik-apik arep dijagakke gawe mantu jane. Iki kok rumangsaku berase saya abot, saya abot. Arep dingo mantu, arep didadekke dhuwit malah dibegal, dimangsane apa. Loh iki kok ireng, loh kok kaya beras dadi wedi lhoh kok wedi. Wadhuh Bapakne... Bapakne.... Adhuh... Bat tobat...tobat...tobat.. Berase malah dadi wedi. Wedi, wedi, wadhuh muga-muga kene katelak Desa Wedhi."

Terjemahan

Perempuan: “Tobat..tobat..tobat lah ada saja orang yang menghadang di jalan. Siapa tau itu adalah orang yang membegal dan tidak memiliki pekerjaan. Hah. Beras yang bagus ini akan dijual untuk mempersiapkan mantu (pernikahan). Ini perasaanku mengapa beras yang dipanggul semakin berat. Akan diuangkan untuk biaya pernikahan justru (hendak) dirampas, apa yang diperkirakan. Loh kenapa berwarna hitam, loh sepertinya beras ini (berubah) menjadi pasir. Wadhuh bapak... adhuh... bat... tobat... tobat... tobat.. beras justru menjadi pasir. Pasir, pasir semoga desa ini (nanti) dikenal sebagai desa Wedhi."

Penyampaian sejarah melalui asal-usul penamaan daerah tersebut memiliki makna dan tujuan tertentu. Salah satu tujuan penamaan berdasarkan peristiwa adalah untuk mengingatkan nilai-nilai yang terkandung dalam latar belakang penamaan daerah tersebut. Sejarah terjadinya 
suatu daerah akan selalu diingat dan dipelajari oleh generasi-generasi selanjutnya sehingga mampu menjadi nilai-nilai yang akan selalu diingat.

\section{Pencapaian Ilmu Pengetahuan Spiritual}

Selain peristiwa-peristiwa yang berkaitan dengan sejarah yang perlu dipelajari dan diingat, terdapat pula pengetahuan yang dapat dianalisis serta dipahami melalui lakon WST. Pengetahuan merupakan suatu wacana yang dihasilkan melalui telaah terhadap pengalaman yang dialami oleh manusia (Al-Qardlawi, 1991:xi). Pengetahuan yang didapatkan berdasarkan pengalaman manusia selaras dengan pemahaman masyarakat Jawa terkait konsep mencapai pemahaman pengetahuan dengan proposisi ngelmu iku kalakone kanthi laku. Pemaknaan kata tersebut adalah ilmu (pengetahuan) yang didapatkan merupakan suatu hasil pencapaian yang dapat diperoleh setelah melalui perjuangan serta pengorbanan (Kholiq, 2011:45). Umumnya, pengetahuan yang bersifat religi atau memuat informasi yang berkaitan dengan ketuhanan, diperoleh dari proses penghayatan terhadap batin serta pemahaman berdasar pengalaman hidup yang dialami (Ciptoprawiro, 1986:38). Pengalaman KAP yang diperoleh dalam perjalanan menuju Jabalkat disertakan dalam tabel berikut dengan penjelasan terkait amanat serta pengetahuan moral yang dapat diketahui berdasarkan peristiwa yang terjadi dalam WST.

Tabel 3. Nilai Moral dalam Wedhare Sadat Tembayat

\begin{tabular}{|c|c|c|c|}
\hline No & Pesan Moral & Peristiwa Terkait & Deskripsi \\
\hline 1 & $\begin{array}{l}\text { Keikhlasan untuk } \\
\text { meninggalkan harta benda } \\
\text { yang dimiliki. }\end{array}$ & $\begin{array}{l}\text { Pembegalan di } \\
\text { Salatiga. }\end{array}$ & $\begin{array}{l}\text { Dengan menunjukkan bahwa isterinya } \\
\text { membawa harta benda dalam perjalanan, } \\
\text { maka Ki Ageng Pandhanaran sudah benar- } \\
\text { benar melepaskan nilai keduniawian. }\end{array}$ \\
\hline & $\begin{array}{l}\text { Amanat untuk mengendalikan } \\
\text { hawa nafsu yang dimiliki oleh } \\
\text { manusia }\end{array}$ & $\begin{array}{l}\text { Taubatan nasuha KAP, } \\
\text { Boyolali, serta } \\
\text { peristiwa Salatiga. }\end{array}$ & $\begin{array}{l}\text { Sikap tamak, rakus, amarah, dan segala } \\
\text { perbuatan negatif yang diakibatkan oleh } \\
\text { hawa nafsu perlu dikendalikan dan } \\
\text { dihilangkan karena dapat menjauhkan diri } \\
\text { dari kebenaran sejati. }\end{array}$ \\
\hline 3 & $\begin{array}{l}\text { Amanat untuk beriman kepada } \\
\text { Allah. }\end{array}$ & Peristiwa Salatiga. & $\begin{array}{l}\text { Peristiwa yang menjadikan manusia } \\
\text { berubah wujud menjadi domba memiliki } \\
\text { makna bahwa segala sesuatu yang } \\
\text { berkaitan dengan takdir akan berlangsung } \\
\text { secara cepat dan tidak terduga, oleh karena } \\
\text { itu Tuhan (Allah) wajib diyakini serta } \\
\text { bersaksi bahwa tiada Tuhan selain Allah } \\
\text { (bersyahadat). }\end{array}$ \\
\hline & $\begin{array}{l}\text { Menjalankan syariat dengan } \\
\text { baik berdasarkan anjuran } \\
\text { dalam agama. }\end{array}$ & $\begin{array}{l}\text { Di dalam pergelaran } \\
\text { disampaikan pesan- } \\
\text { pesan yang berkaitan } \\
\text { dengan sholat dengan } \\
\text { tembang yang } \\
\text { dinyanyikan dan }\end{array}$ & $\begin{array}{l}\text { Tujuan dari pergelaran wayang Tauhid } \\
\text { adalah untuk menyampaikan nilai-nilai } \\
\text { yang berkaitan dengan keislaman dan } \\
\text { keagamaan. Hal-hal yang berkaitan dengan } \\
\text { syariat juga disampaikan sebagai bentuk } \\
\text { syiar kepada penonton. }\end{array}$ \\
\hline
\end{tabular}


5 Manusia sejatinya harus bermanfaat untuk orang lain.

6 Manusia tidak dapat membohongi diri pribadinya. penampilan tokoh

wayang sebagai selingan (tidak masuk ke dalam inti cerita WST).

Peristiwa Salatiga dan desa Wedhi.

Desa Wedhi.
KAP memerintah Seh Dumbo untuk melakukan tapa ngrame sehingga harus memberikan bantuan kepada orang yang membutuhkan. Selain itu, kebermanfaatan untuk orang lain ditunjukkan sendiri oleh KAP dengan membantu Ki dan Nyi Tasik berjualan serabi ketika tinggal di rumahnya.

KAP menyampaikan pesan bahwa manusia bisa berbohong melalui ucapan kepada orang lain, namun sesungguhnya tidak akan pernah bisa untuk membohongi diri pribadinya.

Pengetahuan yang terdapat dalam lakon WST secara tersirat melalui peristiwaperistiwa yang telah terjadi dan dialami oleh KAP. Pengetahuan yang diperoleh berupa pesan maupun peristiwa yang dialami. Pengetahuan yang didapat merupakan analisis terhadap nilainilai kebudayaan serta amanat-amanat yang diperoleh baik yang disampaikan secara langsung atau tersirat. Nilai-nilai kebudayaan yang berkaitan dengan ilmu pengetahuan terkait pemahaman moral juga disampaikan dengan pemahaman terhadap sikap hidup manusia dalam kebudayaan Jawa. Adapun sikap hidup tersebut ditemukan dalam sikap dan sifat dari tokohtokoh yang ada dalam lakon yakni wedi, isin, sungkan serta teken, tekun, dan tekan.

Wedi, isin, dan sungkan yang berarti perasaan takut, malu, dan tidak enakan merupakan sikap hormat yang selalu ditunjukkan oleh masyarakat Jawa untuk bersikap sesuai dengan derajat serta kedudukan (Suseno, 1984:60). Dalam buku Etika Jawa, konsep wedi, isin, dan sungkan direalisasikan melalui contoh sapaan dan percakapan antara orang yang lebih tua dan muda, perilaku hormat dengan orang yang lebih senior, serta pendidikan nilai kesopanan pada anak. Kesadaran terhadap kesalahan dengan menerapkan prinsip wedi, isin, dan sungkan merupakan indikator bahwa pribadi telah memahami sikap yang seharusnya dilakukan atau telah berpikiran matang (Suseno, 1984:65). Sikap wedi, isin, dan sungkan ditampilkan dalam lakon WST ketika tokoh-tokoh antagonis telah menyadari kesalahan yang dilakukannya dengan peringatan yang disampaikan oleh Sunan Kalijaga. Berbeda dengan hal itu, dalam lakon WST sikap ini dimunculkan sebagai sikap yang didasarkan atas rasa malu 
terhadap perbuatannya yang salah. Berikut merupakan kutipan percakapan yang berkaitan dengan penyesalan atas perbuatan salah yang telah dilakukan.

KAP : "Oh (sujud, salim, menunduk) Wadhuh Kanjeng Sunan. Ngantos kula boten emut purwaduksina Rama. Bapa Sunan inggih sampun rawuh wonten ing Semarang. Nyuwun gunging pangapunten ngantos kula lali purwaduksina, Bapa."

Terjemahan

KA : "Oh. Waduh Kanjeng Sunan. Saya sudah tidak ingat Rama, Bapa Sunan juga telah tiba di Semarang, mohon maaf sebesar-besarnya hingga saya sudah lupa, Bapa."

Melalui percakapan tersebut, KAP mengungkapkan bahwa ia telah lupa purwa duksina. Purwa duksina merupakan kendali atau kontrol terhadap jiwa manusia, sehingga lali purwa duksina berarti kehilangan kendali terhadap jiwa yang dilakukan oleh pemiliknya (jiwa) (Endraswara, 2012:6). Umumnya berkaitan dengan kelalaian terhadap nilai-nilai atau norma yang seharusnya dilakukan. Melalui peristiwa yang terjadi dapat diketahui bahwa konsep wedi, isin, dan sungkan yang dikandung dalam lakon berkaitan dengan kesadaran akan kesalahan serta wujud pelepasan ego yang telah dilakukan. Ego yang berkaitan dengan perasaan bahwa diri pribadi paling benar dan tidak ada tandingan dapat dilebur jika seseorang mampu memahami dan mempraktekkan konsep wedi, isin, dan sungkan.

Wedi, isin, dan sungkan umumnya mengenai upaya untuk melepaskan apa yang ada dalam diri. Berbeda dengan hal itu, terdapat konsep hidup masyarakat Jawa untuk mewujudkan kehidupan yang lebih baik lagi yakni keyakinan untuk teken, tekun, sehingga tekan. Konsep teken, tekun, dan tekan merupakan konsep yang mendasari keadaan kehidupan yang selaras dengan didasari oleh landasan berupa aturan-aturan hidup yang dijalani dengan ketekunan, rajin, dan sungguh-sungguh sehingga dapat mencapai cita-cita hidup yang diinginkan (Endraswara, 2016:240). Sikap teken, tekun, dan tekan disampaikan melalui KAP dengan perjalanan laku yang dijalaninya. Perjalanan yang didasarkan pada kesadaran bahwa ia telah mendapatkan nilai kehidupan berdasar landasan yang pasti, dan menjalaninya dengan tekun maka berbuah tercapainya tujuan laku tersebut. Sunan Kalijaga juga menyampaikan pesan yang berkaitan dengan sikap tekun. Berikut merupakan percakapan yang diujarkan.

Sunan Kalijaga: "Wus, wus Ngger Rana Wijaya lan kabeh wae. Aku bakal nerusake laku, tak pepuji bisa katekan panjangkamu waton teteken kanthi tekun, lakumu bakal tekan." 
Terjemahan

Sunan Kalijaga: "Sudah, sudah nak Rana Wijaya dan semuanya. Aku akan berangkat melanjutkan laku, aku mendoakan agar keinginanmu dapat terpenuhi selama dilakukan dengan tekun, lakumu akan tercapai."

Melalui percakapan tersebut, diketahui bahwa masyarakat Jawa memaknai kehidupan sebagai proses belajar yang harus dilakukan dengan berbekal ketekunan tanpa kenal sikap menyerah dan berputus asa. Tumemen (sebenarnya, kesungguhan) merupakan bekal yang perlu dimiliki untuk menjadi landasan perbuatan yang berkaitan dengan laku, sehingga orang yang benar-benar teguh dalam niatan dan tidak menyeleweng adalah yang dapat mencapai impiannya (Endraswara, 2016:240). Selaras dengan konsep pemikiran masyarakat Jawa, KAP berhasil merampungkan perjalanan yang dilakukan hingga tiba di gunung Jabalkat dan bertemu dengan Sunan Kalijaga. Proses pertemuan antara Sunan Kalijaga dan KAP merupakan hasil dari ketekunan dan perjuangan yang telah dikorbankan dalam proses pembelajaran untuk mencapai kehidupan yang lebih baik lagi.

\section{SIMPULAN}

Kajian "Laku dan Pengetahuan Spiritual Ki Ageng Pandhanaran dalam Lakon Wedhare Sadat Tembayat" menghasilkan kesimpulan yang dapat dijabarkan sebagai berikut.

Laku merupakan sarana pengembangan dan penyempurnaan diri KAP untuk mencapai pengetahuan spititual mengenai keislaman dan keimanan melalui proses perlawanan dan pengendalian terhadap nafsu serta ambisi duniawi yang bergelora di dalam dirinya. Pengendalian, ambisi, serta kepentingan pribadi merupakan ujian terhadap proses laku yang dijalankan. Tantangan, hambatan, serta cobaan dijalani dengan kesungguhan hati dan tekad sehingga mampu terwujud sosok baru dalam diri KAP. Perwujudan sosok baru tidak terlepas dari kondisi masa lalu yang dipenuhi dengan intrik dan konflik diri akibat kesalahan serta kekhilafan yang pernah menyelubungi di dalam hatinya. Proses laku sebagai wujud upaya untuk melebur kesalahan serta mengenali diri pribadi dengan bantuan dari seorang wali yang telah memiliki ilmu pengetahuan terlebih dahulu, yakni Sunan Kalijaga. Sunan Kalijaga merupakan representasi dari ilmu pengetahuan yang telah menuntun KAP dari ketidaktahuan terhadap ajaran agama Islam serta sikap yang bertentangan dengan kebenaran menjadi sosok yang beriman Islam serta memahami moral dan memiliki pengetahuan terhadap diri pribadi. Perjalanan untuk mencapai berilmu pengetahuan spiritual Islam disertai dengan peristiwa- 
peristiwa yang tidak disangka-sangka yang beberapa mengandung kekuatan-kekuatan magis. Melalui perjalanan, perjuangan, dan segala hal yang dialami dalam mencapai pengetahuan spiritual, KAP mampu mencapai tataran sebagai wali lukba (wali penutup) yang saleh dan suci untuk menyebarkan agama Islam.

\section{DAFTAR PUSTAKA}

Endraswara, S. (2012). Budaya Spiritual sebagai Wahana Pembentukan Karakter Bangsa. Makalah Sarasehan Budaya Spiritual , 1-11.

Al-Qardlawi, Y. (1991). Metode dan Etika Pengembangan Ilmu Perspektif Sunnah. Bandung: PT Remaja Rosdakarya.

Berg, C. (1985). Penulisan Sejarah Jawa. Jakarta: Bhratara Karya Aksara.

Ciptoprawiro, A. (1986). Filsafat Jawa. Jakarta: Balai Pustaka.

Dandhel, S. A. (2013). Penyebaran Agama Islam di Pulau Jawa oleh Sunan Kalijaga melalui Media Wayang Kulit. UI, 3-12.

Darmoko. (2014). Konsep Darma dalam Budaya Jawa. Jurnal IKADBUDI Volume 3. Yogyakarta: UNY.

Endraswara, S. (2013). Falsafah Kepemimpinan Jawa. Jakarta: PT Buku Seru. . (2016). Berpikir Positif Orang Jawa. Yogyakarta: PT Buku Seru.

Jong, D. (1976). Salah Satu Sikap Hidup Orang Jawa. Yogyakarta: Penerbitan Yayasan Kanisius.

Kholiq, M. (2011). Menggali Keberadaan Nilai-Nilai Kearifan Lokal pada Masyarakat Jawa bagi Pembangunan Peradaban Indonesia di Masa Depan. Prosiding PESAT Universitas Gunadarma, S44-S48.

Koetjaraningrat. (1984). Kebudayaan Jawa. Jakarta: PN Balai Pustaka.

Muhammad Syaiful Hidayat dan Yunus Hanis Syam. (2009). Mengetuk Pintu Taubat. Yogyakarta: Penerbit Mutiara Media.

Mulyono, S. (1979). Wayang dan Karakter Manusia. Jakarta: PT Indayu Press.

Murtiyoso, B. (2004). Pertumbuhan dan Perkembangan Seni Pertunjukan Wayang. Surakarta: Citra Etnika Surakarta. 
Prawiroatmodjo, S. (1957). Bausastra Jawa Indonesia. Jakarta: PT Inti Idayu Press.

Rahyono, F. (2015). Kearifan Budaya dalam Kata. Jakarta: Wedatama Widya Sastra.

Shohib, M. (2015). Taubat sebagai Metode Dasar Psikoterapi. Psychology Forum UMM, $539-534$.

Simuh. (1988). Mistik Islam Kejawen Raden Ngabehi Ranggawarsita. Jakarta : Penerbit Universitas Indonesia .

Soemantri, G. R. (2005). Memahami Metode Kualitatif. Makara Volume 9 no 2, 57-65.

Solichin. (2016). Filsafat Wayang Sistematis . Jakarta: Sena Wangi. . (2017). Ensiklopedi Wayang Indonesia . Bandung : Mitra Sarana Edukasi.

Suseno, F. M. (1984). Etika Jawa . Jakarta: PT Gramedia.

Sviri, S. (2006). Cita Rasa Mistis. Bandung: Pustaka Hidayah.

Teeuw, A. (2013). Sastra dan Ilmu Sastra. Bandung: PT Dunia Pustaka Jaya.

Wahyudi, A. (2013). Rahasia Makrifat Jawa. Jakarta: Dipta.

Wahyudi, A. (2014). Pesona Kearifan Jawa. Yogyakarta: Dipta.

Woodward, M. R. (1999). Islam Jawa Kesalehan Normatif Versus Kebatinan. Yogyakarta: LKiS Yogyakarta.

Zoetmulder, P. (1991). Manunggaling Kawula Gusti Pantheisme dan Monisme dalam Sastra Suluk Jawa. Jakarta: PT Gramedia. 